\title{
Masks, Seat Belts, and the Politicization of Public Health
}

\author{
Dawn Harris Sherling, MD*, Meagan Bell, BA²
}

${ }^{1}$ Charles E Schmidt College of Medicine, Florida Atlantic University, Boca Raton, Florida; ${ }^{2}$ The Conservatory School, North Palm Beach, Florida.

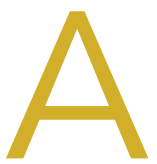

t the time this piece was written, 54 Florida hospitals reported no available intensive care unit (ICU) beds'; hospitals in Miami-Dade County even started sending patients to neighboring Broward County for care despite Broward County also reporting a hospital bed shortage. Patients might even have needed to be transferred further north to Palm Beach County. ${ }^{2}$ Miami-Dade County was diagnosing over 100 cases with SARS-CoV-2 per 100,000 residents per day at one point, with a test positivity rate of over $25 \%$ that suggests testing is inadequate and many more would-be positive tests are being missed. ${ }^{3}$ While certain parts of the United States seem to have gained some semblance of control over the novel coronavirus, Florida appears to be in a downward spiral of high infection rates and increasing hospitalizations.

It didn't have to go this way.

According to Robert Redfield, MD, Director of the Centers for Disease Control and Prevention, wearing a mask significantly reduces SARS-CoV-2 transmission. If community masking were increased only modestly, disease transmission could be curtailed enough to prevent many stay-at-home orders and reduce losses of an estimated $\$ 1$ trillion in gross domestic product ${ }^{4}$ while also providing incalculable improvements in morbidity and mortality. Some experts believe that, while wearing a mask can protect others, it can also protect the wearer. ${ }^{5}$

That masking should be universal has become the accepted public health sentiment during this pandemic. Yet at the time of writing this article, there was still no law mandating masks in Florida, perhaps due to a significant but vocal minority-those who have personal concerns about wearing a mask and little concern about transmitting the virus to other, more vulnerable populations. This was the reason that one of the authors (M.B.) campaigned tirelessly for mandatory masking at Palm Beach County Commission meetings, one of which made the international news because of the outrageous and seemingly heartfelt statements made by several antimask advocates. ${ }^{6}$

\section{AN ORGANIZED AND OUTSPOKEN MINORITY}

At the Palm Beach County Commission, organized antimask advocates arrived hours before the start of the meeting, coming in two buses. Because of social distancing guidelines and

*Corresponding Author: Dawn Harris Sherling, MD, FACP; Email: dawnsherling@gmail.com; Telephone: 561-297-0022; Twitter: @dharrissherling. Published online first October 21, 2020.

Received: July 20, 2020; Revised: August 17, 2020; Accepted: August 19, 2020 (c) 2020 Society of Hospital Medicine DOI 10.12788/jhm.3524 seating limitations, they were able to fill many of the open seats at the meeting, making it appear that the antimask advocates far outnumbered those in favor of mask laws. Despite their tactics of screaming and intimidation, a law mandating masks in the county passed unanimously, though medical exemptions for those with chronic obstructive pulmonary disease, asthma, or "other conditions that reduce breathing" and religious exemptions for "persons for whom wearing a facial covering conflicts with their religious beliefs or practices" were included. ${ }^{7}$ After the meeting, police escorts were required by those in favor of masks, while the county commissioners had to lock themselves behind chamber doors.

The antimask campaigners were already known to M.B., a teacher, from previous gatherings she had attended in support of firearm legislation aimed at reducing gun violence. The same antimask advocates at the County Commission meeting had previously gathered as counter-protesters at this prior event, heckling and threatening those advocating for improving gun safety through legislation such as background checks. While it should not be, mask wearing and the laws mandating it have become a question of politics rather than one based in scientific evidence.

\section{POLITICIZATION OF PUBLIC HEALTH IN FLORIDA AND ITS CONSEOUENCES}

The absence of mandatory masking laws in populations hesitant to wear them, combined with the rush to reopen businesses, resulted in increasing death rates in Florida, with 7-day averages continuing in an upward trajectory and over 7,000 deaths being reported as of August 3, 2020.8 A small glimmer of hope was raised on that day, when fewer than 100 deaths for the previous day were reported, although one wonders if the weekend's Hurricane Isaias preparations may have delayed some reporting.

In the face of mounting death counts and increasingly stressed hospitals, Florida's governor, Ron DeSantis, has not heeded calls to institute new regulations, instead deferring to localities. This is perhaps good news considering Georgia's governor, Brian Kemp, has spoken out against local mask laws and has said that mandating wearing them, even at the local

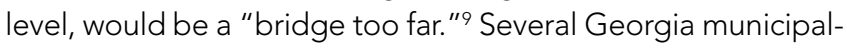
ities defied the governor, passing mandatory masking for their populations anyway, prompting Governor Kemp to file a lawsuit against the city of Atlanta, which he subsequently dropped after a judge ordered the state and city into mediation. ${ }^{10}$

The idea that the state should create laws to regulate the health and safety of the population has been met with resistance in the past where there is a greater degree of libertarian 
and antipaternalistic thinking. ${ }^{11}$ Campaigning against public health laws is not a new phenomenon. In the 1970s and 1980s, mandatory seat belt laws were met with significant resistance by a vocal minority, with the most common predictors for opposing these laws noted as holding beliefs that seat belts were ineffective, inconvenient, or uncomfortable ${ }^{12}$ - the same arguments that have been made against masks. Additionally, having lower educational attainment, less income, and younger age were predictors of being against mandatory seat belt laws. ${ }^{12}$

\section{THE IMPORTANCE OF COMMUNITY ENGAGEMENT}

In response to a vociferous and somewhat organized minority, which has, in many cases, intimidated state and local politicians into inaction, community organizers have put out the call for many more citizens to make their voices heard. This seemed to have had an impact on the Palm Beach County commissioners, one of whom tried to demonstrate that there was broad support for passing a mandatory masking law during the commission meeting by bringing a stack of printed-out communications he had received in favor of it. Community organizers and public health advocates generally have an easier time reaching local officials, whereas it can be more difficult to engage other government officials farther away in state capitals, especially in larger states such as Florida. The organizers can also appeal to the fact that the local officials must live in the communities they represent and do not want to suffer from the spread of SARSCoV-2 and overflowing hospitals. While local officials may be ill equipped to handle a global pandemic, appealing to the community has been somewhat effective in putting pressure on these officials to get a patchwork of local laws, which hopefully will have an impact on Florida's surge numbers.

In the absence of a statewide mandatory masking law in Florida, several municipalities have instituted their own restrictions. Counties with some of the largest cities, such as Miami, Fort Lauderdale, Tampa, and Orlando, have required that masks be worn in public since June or early July..$^{13}$ These restrictions, however, were implemented later than states in the northeastern United States, which have required masks since April or May and before significant reopening of businesses took place, in contrast to the sequence observed in Florida.

In the absence of political leadership, Florida businesses are increasingly taking up the charge and mandating that employees work from home, while others are requiring that employees and customers wear masks. Following New York-based grocer Key Foods and national chains like Whole Foods, both of which have long required that Florida customers wear masks, Florida's ubiquitous Publix Supermarkets mandated masks in over 800 of their stores beginning July 21.14

While individual businesses and localities should be commended for their efforts, unfortunately, this may not be enough to dampen the surge. A tool developed by Harvard-based researchers has labeled Florida and several other neighboring states as having severe spread, necessitating the need for stayat-home orders to be reinstated..$^{15}$

\section{CONCLUSION}

Florida is currently a global epicenter for COVID-19 diagnoses, with the state reporting nearly 600,000 cases as of August $17,{ }^{8}$ more than most countries with larger populations. Florida faces many barriers to gaining control over the virus, including a vocal and organized minority that has opposed public health measures, an unwilling state government and ill-equipped local officials, and an underfunded safety net if stay-at-home orders were to be issued. Appealing to the public and elected officials with science, sanity, and support for those who want to prevent the spread of COVID-19 may provide one solution for gaining some control over the pandemic.

Disclosures: The authors have nothing to disclose.

\section{References}

1. Hospital ICU Beds Census and Staffed Availability as Reported in ESS. My Florida. Accessed July 30, 2020. https://bi.ahca.myflorida.com/t/ABICC/ views/Public/lCUBedsHospital

2. Goodman CK. Broward hospitals nearing capacity with overflow patients from Miami-Dade. South Florida Sun Sentinel. July 28, 2020. Accessed August 3, 2020. https://www.sun-sentinel.com/coronavirus/fl-ne-broward-hospitals-getting-overflow-20200728-akz7k5wmubb2billpnofsqtqdy-story.html

3. Miami-Dade County, FL. Covid Act Now. Accessed August 3, 2020. https:// covidactnow.org/us/fl/county/miami_dade_county?s=790144

4. Brooks JT, Butler JC, Redfield RR. Universal masking to prevent SARS-CoV-2 transmission - the time is now. JAMA. Published online July 14, 2020. https:// doi.org/10.1001/jama.2020.13107

5. Gandhi M, Beyrer C, Goosby E. Masks do more than protect others during COVID-19: reducing the inoculum of SARS-CoV-2 to protect the wearer. J Gen Intern Med. 2020;1-4. https://doi.org/10.1007/s11606-020-06067-8

6. 'They want to throw God's wonderful breathing system out.' BBC News. June 25, 2020. Accessed August 3, 2020. https://www.bbc.com/news/av/ world-us-canada-53174415/they-want-to-throw-god-s-wonderful-breathingsystem-out

7. Palm Beach County Facial Coverings Frequently Asked Questions. Palm Beach County: Discover the Palm Beaches...the Best of Everything. Updated June 26, 2020. Accessed July 30, 2020. https://discover.pbcgov.org/PDF/ COVID19/PBC-Facial-Coverings-FAQs.pdf

8. Florida COVID-19 Response. Accessed August 17, 2020. https://floridahealthcovid19.gov/

9. Flynn M, lati M. Georgia Gov. Brian Kemp sues Atlanta over mask requirement as coronavirus surges in the state. Washington Post. July 16, 2020. Accessed August 3, 2020. https://www.washingtonpost.com/nation/2020/07/16/kempgeorgia-mask-mandates/

10. Jamerson J. Georgia Gov. Kemp drops lawsuit against Atlanta mayor over coronavirus restrictions. Wall Street Journal. August 13, 2020. Accessed August 17, 2020. https://www.wsj.com/articles/georgia-gov-kemp-drops-lawsuit-against-atlanta-mayor-over-coronavirus-restrictions-11597347685

11. Giubilini A, Savulescu J. Vaccination, risks, and freedom: the seat belt analogy. Public Health Ethics. 2019;12(3):237-249. https://doi.org/10.1093/phe/ phz014

12. Morelock S, Hingson RW, Smith RA, Lederman RI. Mandatory seatbelt law support and opposition in New England-a survey. Public Health Rep. 1985;100(4):357-363.

13. Muller B. Most major Florida cities now require wearing face masks in public. News4Jax. June 19, 2020. Updated June 19, 2020. Accessed August 3, 2020. https://www.news4jax.com/news/local/2020/06/19/major-florida-cities-nowrequire-use-of-face-mask-in-public-places/

14. Ward B. Publix to mandate face masks for all stores starting next week. Tampa Bay Business Journal. July 16, 2020. Updated July 16, 2020. Accessed August 3, 2020. https://www.bizjournals.com/tampabay/news/2020/07/16/ publix-to-mandate-face-masks-for-all-stores-starti.html

15. COVID Risk Levels Dashboard. Pandemics explained: unlocking evidence for better decision making. Accessed August 3, 2020. https://globalepidemics. org/key-metrics-for-covid-suppression/ 